\title{
Breed and Age as Risk Factors for Canine Mammary Tumours
}

\author{
J. ZATLOUKAL, J. LORENZOVÁ, F. TICHÝ, A. NEČAS, H. KECOVÁ, P. KOHOUT
}

Small Animal clivic, department of Surgery, University of Veterinary and Pharmaceutical Sciences, Brno, Czech Republic

Received August 15, 2003

Accepted March 3, 2005

\begin{abstract}
Zatloukal J., J. Lorenzová, F. Tichý, A. Nečas, H. Kecová, P. Kohout: Breed and Age as Risk Factors for Canine Mammary Tumours. Acta Vet. Brno 2005, 74: 103-109.

Mammary tumours in 214 dogs were evaluated at the Department of Surgery and Orthopaedics, Veterinary and Pharmaceutical University Brno, between 1997 and 2001. Lesions of the mammary gland were classified as dysplasia/hyperplasia, benign and malignant tumours in 19, 61 and 134 patients, respectively. When there were different lesions of the mammary gland in one individual, the patient was classified according to the most malignant one. The above-mentioned patients were compared to the population of 17053 dogs treated during the same period to determine age and breed predisposition.

Considering the lesions of the mammary gland, the highest relative risk of dysplasia/hyperplasia, benign tumours and malignant tumours was at the age of 8,10 and 13 years, respectively. Our results thus confirm the previous studies stating the highest incidence after 10 years of age.

Poodles, English Cocker Spaniels and Dachshunds had a statistically significant relative risk developing benign and malignant tumours of the mammary gland ( $\chi^{2}$-test, $\left.p<0.01\right)$, confirming conclusions of previous studies concerning these breeds. We did not, however, prove higher relative risk in Irish Setters, Labrador Retrievers and Boxers.
\end{abstract}

Breast neoplasms, histopathology, incidence, predisposition, retrospective study

The mammary gland belongs to body areas with the highest incidence of neoplasia. Tumours of the mammary gland in female dogs represent up to $42 \%$ of all tumours (Johnson 1993; Dorn et al. 1968). They occur with much higher incidence than in other females of domestic animals and women (Brodey et al. 1983; S chneider 1970).

Risk factors associated with the increased occurrence of mammary tumours in female dogs have already been studied. Higher incidence was found after the 6th year of age with the maximum being 9 to 11 years. Female dogs younger than 2 years were rarely affected (S chneider 1970; B rodey et al. 1983). Increased incidence of mammary tumours was found in many large as well as smaller breeds of dogs. The lowest occurrence was found in mongrels, Boxers and Chihuahuas (Dorn et al. 1968; Brodey et al. 1983; Cohen et al. 1974). Spayed dogs had a 3 to 7 times lower incidence of mammary tumours than the intact ones (Mulligan 1975; Priester 1979; Hahn et al. 1992; Alenza et al. 2000). The effect of spaying on the decreased incidence of mammary tumour, however, depended on the age of the dog at the time of surgery. The most significant decrease of incidence was found in females spayed prior to their first oestrus $(0.5 \%$ incidence as compared to intact female dogs $)$ and between the first and second oestrus $(8 \%)$. Advanced age at the time of spaying increases the incidence of tumors ( $26 \%$ between the second and fourth estrus) and no positive effect of spaying was found after the fourth estrus (Misdorp 1988; Schneider et al. 1969). Characteristics such as abnormal oestrous cycle, false pregnancy, pregnancy, number of litters, number of puppies and their size were found not to represent risk factors even though some associations were confirmed (Brodey et al. 1966; Schneider et al. 1969; Schneider 1970). Because in women there 
was higher incidence of breast tumours with fatty diet, dietetic predisposition factors were also considered in dogs. A higher incidence of mammary tumours was found in dogs receiving a "home-made" diet and "red meat" compared to commercial diets. Obesity in young animals (up to 1 years of age) is another risk factor for developing tumours even at a later age (Alenza et al. 2000; Sonnenschein et al. 1991; Alenza et al. 1998). The goal of our study was to evaluate the risk of developing canine mammary tumours in relation to age and breed.

\section{Materials and Methods}

Breed and age predisposition to benign and malignant mammary tumours was evaluated in dogs treated at the Department of Surgery and Orthopaedics of the Small Animal Clinic, Veterinary and Pharmaceutical University Brno between 1997 and 2001. Only patients with histological classification of specimens obtained during surgery were included into the study. Lesions of the mammary gland were classified for purposes of this study as dysplasia/hyperplasia, benign tumours and malignant tumours. When there were different lesions in one dog, the patient was classified according to the most malignant one (dysplasia $\rightarrow$ benign neoplasia $\rightarrow$ malignant neoplasia consider reversing the order, starting with malignant $\rightarrow$ benign $\rightarrow$ dysplasia). In patients treated for mammary lesions repeatedly, data obtained on the first occasion was considered for purposes of this study. All dogs referred to the Department of Surgery and Orthopaedics of the Small Animal Clinic, Veterinary and Pharmaceutical University Brno between 1997 and 2001 were included in the control group.

The age predisposition to dysplasia, benign neoplasia and malignant neoplasia of the canine mammary gland was expressed as the mean and most frequent (modus) age. By comparing data with the control group we determined the relative risk (OR) of mammary gland lesions in individual age categories for each group.

The breed predisposition to tumorous changes (including dysplasia/hyperplasia) and malignant neoplasia of the mammary gland was evaluated only in breeds, where the number of treated dogs amounted to at least 100 during years 1997 to 2001 . For each breed we determined the relative risk (OR), which was then compared to other dog breeds using $\chi^{2}$ test.

\section{Results}

A total of 214 dogs were treated for diseases of the mammary gland at the Department of Surgery and Orthopaedics of the Small Animal Clinic, Veterinary and Pharmaceutical University Brno between 1997 and 2001. All dogs were female. Histology of canine mammary gland lesions revealed dysplasia/hyperplasia, benign tumours and malignant tumours in 19,61 and 134 patients, respectively. A total of 17053 dogs (including the abovementioned 214) were treated during this period. Dogs affected by mammary gland tumours thus represented $1.25 \%$ of all the patients treated.

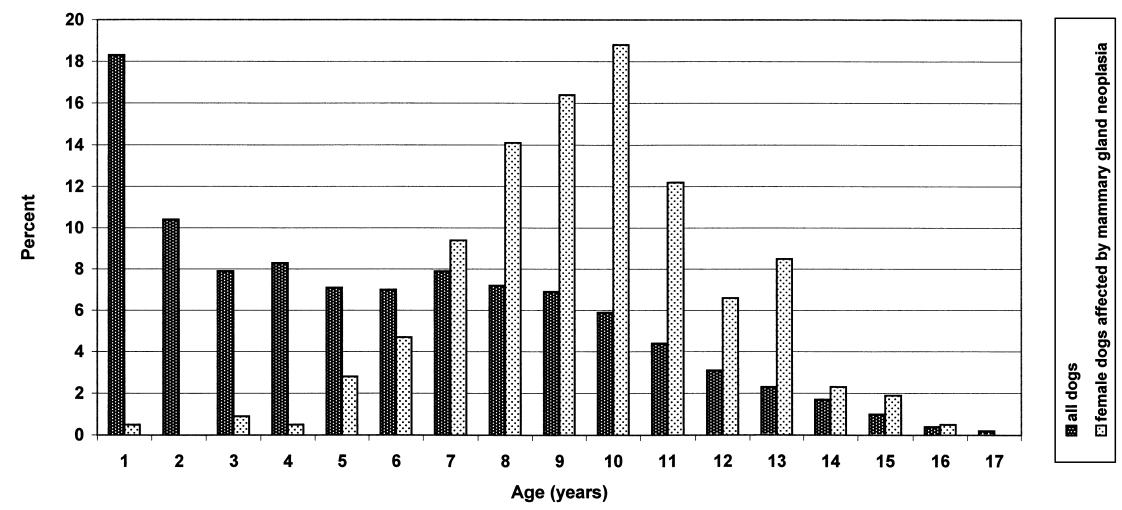

Fig. 1. The relative representation of age categories in all dogs and in female dogs affected by mammary gland neoplasia

Dysplasia/hyperplasia of the mammary gland was found at the mean age of 8.3 years. Dogs were most often affected at the age of 8 years, i.e., the age of the highest relative risk of dysplasia/hyperplasia. Benign tumours were found at the mean age of 8.9 years. Dogs 
were most often affected at the age of 10 years, i.e., the age of the highest relative risk of benign mammary tumours. Malignant tumours were found at the mean age of 10.0 years. Dogs were most often affected at the age of 10 years. The highest relative risk of malignant mammary tumours, however, was found in 13-year old females. Fig. 1 shows the relative representation of age categories in all patients and in female dogs affected by mammary gland neoplasia. The relative risk of tumours of the mammary gland in female dogs in individual age categories is shown in Fig. 2.

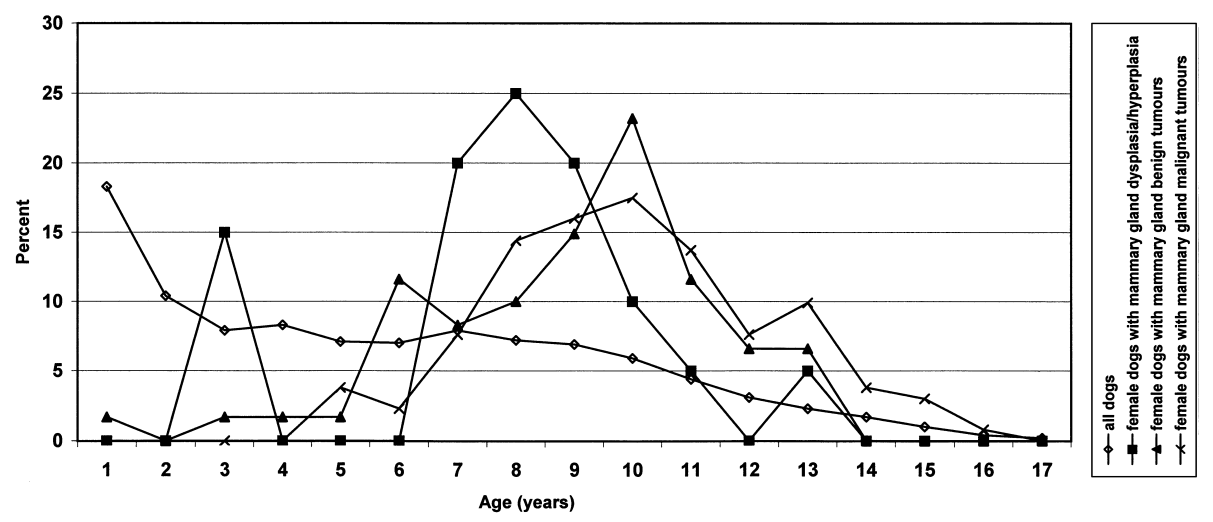

Fig. 2. The relative risk of tumours of the mammary gland in female dogs in individual age categories

The breed predisposition was evaluated in 31 breeds (including mongrels). Table 1 shows the number of dogs evaluated for each breed, number of dogs affected by mammary tumours (including dysplasia/hyperplasia), number of dogs with malignant mammary tumours and the relative risk of canine tumours and canine malignant tumours. We found statistically significant relative risk (OR) to developing benign and malignant tumours of the mammary gland in Poodles, English Cocker Spaniels and Dachshunds $\left(\chi^{2}\right.$ test, $\left.p<0.01\right)$. In other breeds we found no statistically significant difference in relative risk to developing tumours of the mammary gland. In 16 breeds we did not find any malignant mammary tumours and in 14 breeds any mammary tumours at all.

\section{Discussion}

Evaluating benign lesions of the mammary gland we set off dogs affected with dysplasia/hyperplasia. Even though these lesions cannot be classified as tumorous, it is, however, supposed that there is a direct association between dysplastic/hyperplastic lesions and subsequent tumours. That is why these lesions are considered preneoblastic (Brodey et al. 1983; Schneider et al. 1969). According to the current literature on the development of tumorous lesions, these changes are part of the initial stages in the multistage process of carcinogenesis (Rejthar 2002). These changes occur uncommonly prior to the age of 2 years, which was also confirmed by our study. We found that dysplastic/hyperplastic changes of the mammary gland occurred with only one exception after 7 years of age. Their incidence was lower than in benign and malignant tumours. Our study is lacking sufficient number of patients to evaluate dysplastic/hyperplastic lesions, although the actual number of these lesions was much higher because of their occurrance in association with benign or malignant tumours.

Tumours of the mammary gland rarely occur in female dogs younger than 2 years of age. The incidence of tumours then increases after the 5 th year of age with a peak at the age of 1012 years and subsequent decrease (Dorn et al. 1968; Moulton et al. 1970; Mulligan 1975; 
Table 1. Relative risk of canine mammary tumours in selected breeds

\begin{tabular}{|c|c|c|c|c|c|}
\hline & 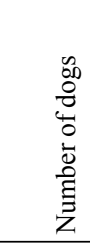 & 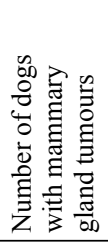 & 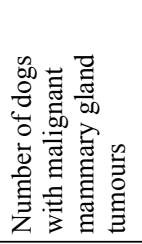 & 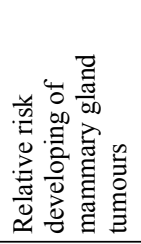 & 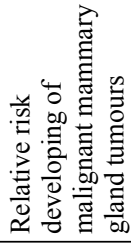 \\
\hline All dogs & 17053 & 217 & 134 & 1.0 & 1.0 \\
\hline Poodle & 1367 & 43 & 29 & 2.5 & 2.7 \\
\hline Standard Schnauzer & 271 & 7 & 1 & 2.0 & 0.5 \\
\hline English cocker spaniel & 797 & 19 & 13 & 1.9 & 2.1 \\
\hline Dachshund & 2053 & 43 & 26 & 1.6 & 1.6 \\
\hline Bullterrier & 149 & 3 & 2 & 1.6 & 1.7 \\
\hline American cocker spaniel & 224 & 4 & 4 & 1.4 & 2.3 \\
\hline Miniature Schnauzer & 298 & 5 & 2 & 1.3 & 0.4 \\
\hline Doberman pinscher & 572 & 8 & 4 & 1.1 & 0.9 \\
\hline Maltese & 149 & 2 & 2 & 1.1 & 1.7 \\
\hline German shepherd & 1811 & 24 & 16 & 1.0 & 1.1 \\
\hline Basset hound & 104 & 1 & 1 & 0.8 & 1.2 \\
\hline Mixed-breed & 2272 & 22 & 14 & 0.8 & 0.8 \\
\hline Miniature pinscher & 155 & 1 & 0 & 0.5 & 0.0 \\
\hline Yorkshire terrier & 419 & 2 & 1 & 0.4 & 0.1 \\
\hline Golden retriever & 200 & 1 & 0 & 0.4 & 0.0 \\
\hline Am. pitbullterrier & 225 & 1 & 0 & 0.3 & 0.0 \\
\hline Boxer & 386 & 1 & 1 & 0.2 & 0.3 \\
\hline Labrador retriever & 292 & 0 & 0 & 0.0 & 0.0 \\
\hline Rottweiler & 343 & 0 & 0 & 0.0 & 0.0 \\
\hline Spitz & 237 & 0 & 0 & 0.0 & 0.0 \\
\hline Great dane & 249 & 0 & 0 & 0.0 & 0.0 \\
\hline Rhodesian ridgeback & 146 & 0 & 0 & 0.0 & 0.0 \\
\hline Beagle & 113 & 0 & 0 & 0.0 & 0.0 \\
\hline Pekingese & 224 & 0 & 0 & 0.0 & 0.0 \\
\hline Dalmatian & 209 & 0 & 0 & 0.0 & 0.0 \\
\hline Am. staffordshire terrier & 142 & 0 & 0 & 0.0 & 0.0 \\
\hline Brazilian fila & 102 & 0 & 0 & 0.0 & 0.0 \\
\hline Chihuahua & 119 & 0 & 0 & 0.0 & 0.0 \\
\hline Irish setter & 105 & 0 & 0 & 0.0 & 0.0 \\
\hline French bulldog & 139 & 0 & 0 & 0.0 & 0.0 \\
\hline Shar-pei & 120 & 0 & 0 & 0.0 & 0.0 \\
\hline
\end{tabular}

Cohen et al. 1974). This trend is in correspondence with the mean age of dogs affected with mammary tumours mentioned in various studies and varying from 9 to 11 years ( $\mathrm{Schneider}$ 1970; Cotchin 1958; Fowler et al. 1974; Mitchell et al. 1974). In our study the mean age of dogs with benign and malignant mammary lesions was 8.9 and 10.0 years, respectively. Benign neoplastic lesions occurred at a moderately earlier age than the malignant ones. Our results confirm previously published data, which proved that dogs with benign neoplasia are 1-2 years younger than those suffering from malignancies (Moulton 1990).

In our group of patients we noticed a trend of increasing percentage of malignant neoplasia with the advancing age of patients. This trend is in accordance with the current knowledge 
on the carcinogenesis stating the fact that the growing age results in the accumulation of tumorogenous factors leading to malignant tumours (Rejthar 2002). Similar results were also obtained by Taylor et al. (1976) in a colony of laboratory Beagles. These authors found that as the age increases the incidence of benign and malignant mammary tumours increases. While the incidence of benign tumours after 14 years of age decreases, the contrary is true for malignant tumours. Incidence of tumours at a certain age of dogs is a better characteristic than the mean age or the frequency of occurrence of mammary tumours in individual age categories. Regarding the basic collection in our study, we did not use the determination of the incidence as in other studies (Taylor et al. 1976; Dorn et al. 1968; Schneider 1970), but we determined the relative risk (OR) of benign and malignant neoplasia of the mammary gland for each age category. This relative risk better characterises the differences in the age predisposition to benign and malignant tumours. The highest relative risk values of malignant and benign tumours were at 13 and 10 years of age, respectively (change to have benign first then malignant to be consistent with the rest of the paper). The decrease in relative risk of malignant tumours of the mammary gland corresponds with the drop in incidence of malignant mammary tumours in the natural population of dogs (Schneider 1970; Dorn et al. 1968). Another study evaluating a closed colony of laboratory Beagles, however, found growing incidence of malignant tumours of the mammary gland up to the highest age categories (T a y lor et al. 1976). Similar trends were obtained by extensive study on spontaneous tumours of the mammary gland, in which the incidence of mammary tumours grew up to the age of 14 years (Boldizsar et al. 1992). It is also our opinion that in the natural population of dogs the risk of tumours of the mammary gland increases up to a high age but that the system of data collection misrepresents the results in higher age categories. For example, in our group of patients the tissue samples were collected during surgery. This procedure, however, was often rejected by owners of elderly dogs that often suffered from concurrent diseases. These factors thus, in our opinion, may lead to a false drop in the relative risk of malignant tumours after the age of 13 years.

A considerably higher breed predisposition to mammary tumours was found in pure breed dogs compared to mongrels (Dorn et al. 1968). Even though not significant, there was also a higher relative risk of mammary tumours in pure breed dogs in our study. A number of breeds, most often hunting dogs, have already been reported to be predisposed to mammary tumours, namely Airedale Terrier, Brittany Spaniel, Boston Terrier, Cocker Spaniel, English Setter, English Springer Spaniel, Fox Terrier, German Shorthaired Pointer, Great Pyrenees, Irish Setter, Keeshond, Labrador Retriever, Pointer, Dachshund, Poodle and Samoyed (Cohen et al. 1974; Dorn et al. 1968; Mitchell et al. 1974; Moulton et al. 1970; Dahme and Weiss 1958; Sandersleben 1958; Mac Vean et al. 1978). Like other authors (Cohen et al. 1974; Mitchell et al. 1974; Moe 2001), we found statistically significant predisposition to tumours of the mammary gland in Poodles, English Cocker Spaniels and Dachshunds. We did not evaluate predisposition in other breeds previously confirmed to have a predisposition for tumor development because some of then such as Airedale Terrier, English Springer Spaniel and German Shorthaired Pointer were represented in too low numbers. Preliminary results confirm that the risk of mammary tumours in these breeds is higher than in the common population but we are currently unable to evaluate the statistical significance. In Labrador Retrievers and Irish Setters we encountered no case of mammary tumours despite a high number of patients examined. For the Irish Setter, we believe that this might be due to an actual lower predisposition of this breed to mammary gland tumours. In the Labrador Retrievers it is probably a false negative finding due to an increase of popularity in last few years, which results in high numbers of younger age dogs. Number of older dogs with higher incidence of mammary tumours is still low. Considerably lower risk of mammary gland tumours was found in Chihuahuas and 
Boxers (Cohen et al. 1974; Dorn et al. 1968). In these two breeds we also found lower incidence of mammary tumours than in the common population. Results concerning Boxers, however, are controversial according to another study (Moe 2001). This breed belongs to one of four breeds most predisposed to mammary tumours. To determine a more accurate breed predisposition, it will be necessary to enlarge the collection and obtain data on less popular dog breeds. It would also be useful to evaluate family predisposition, which might explain different results concerning some breeds in various countries. Another aspect to evaluate is the difference in predisposition to benign and malignant lesions of the mammary gland. While malignant tumours amounted on average to $61 \%$ of all mammary lesions, it was only $25 \%$ in Miniature and Standard Schnauzers. Again, proper evaluation of these results needs more data.

\section{Plemenná a věková predispozice $k$ nádorům mléčné žlázy u fen}

Nádory mléčné žlázy jsme sledovali na Oddělení chirurgie a ortopedie, Veterinární a farmaceutické university Brno u 214 pacientů v letech 1997 až 2001. Změny na mléčné žláze byly klasifikovány jako dysplazie/hyperplazie u 19 fen, benigní tumory u 61 fen a maligní tumory u 134 fen. Pokud byl zjištěn výskyt různých změn na mléčné žláze u jednoho jedince současně, byl pacient dále posuzován podle malignější léze. Tito pacienti byli porovnáni s populací 17053 pacientů ošetřených za stejné období pro stanovení věkové a plemenné predispozice.

Feny vykazovaly u změn na mléčné žláze nejvyšší relativní riziko pro vznik dysplazie/hyperplazie ve věku 8 roků, pro vznik benigních tumorů 10 roků a pro vznik maligních tumorů 13 roků. Naše výsledky tak byly souhlasné s předchozími studiemi prokazujícím nejvyšší incidenci po 10 letech stáří.

Statisticky významnou predispozici k nádorům a maligním nádorům mléčné žlázy u fen jsme prokázali u pudlů, anglických kokršpanělů a jezevčíků $\left(\chi^{2}\right.$ test, $\left.p<0,01\right)$ a potvrdili jsem tak u těchto plemen závěry předchozích studií. Naopak jsme neprokázali zvýšenou predispozici u irských setrů, labradorských retrívrů a boxerů.

\section{Acknowledgements}

This work was supported by research project of M·MT no. 161700002 .

\section{References}

ALENZA, DP, RUTTEMAN, GP, PENA, L, BEYNEN, AC, CUESTA, P 1998: Relation between habitual diet and canine mammary tumors in case-control study. J Vet Int Med 12: 132-139

ALENZA, DP, PENA, L, DEL CASTILLO, N, NIETO, AI 2000: Factors influencing the incidence and prognosis of canine mammary tumours. J Small Anim Pract 41: 287-291

BOLDIZSAR, H, SZENCI, O, MURAY, T, CSENKI, J 1992: Studies on canine mammary tumours. I. Age, seasonal and breed distribution. Acta Vet Hung 40: 75-87

BRODEY, RS, FIDLER, IJ, HOWSON, AE 1966: The relationship of estrous irregularity, pseudopregnancy, and pregnancy to the development of canine mammary neoplasms. J Am Vet Med Assoc 149: 1047-1049

BRODEY, RS, GOLDSCHMIDT, MH, ROSZEL, JR 1983: Canine mammary gland neoplasms. J Am Anim Hosp Assoc 19: 61-90

COHEN, D, REIF, JS, BRODEY, RS, KEISER, H 1974: Epidemiological analysis of the most prevalent sites and types of canine neoplasia observed in a veterinary hospital. Cancer Res 34: 2859-2868

COTCHIN, E 1958: Mammary neoplasms of the bitch. J Comp Path Ther 68: 1-22

DAHME, E, WEISS, E 1958: Zur Systematik der Mammatumoren des Hundes. Dtsch Tier 65: 458-461

DORN, CR, TAYLOR, DO, SCHNEIDER, R, HIBBARD, HH, KLAUBER, MR 1968: Survey of animal neoplasms in Albeda and Contra Costa counties, California. II. Cancer morbidity in dogs and cats from Almeda county. J Nath Cancer Inst 40: 307-318

FOWLER, EH, WILSON, GP, KOESTNER, A 1974: Biological behavior of canine mammary neoplasms based on a histological classification. Vet Pathol 3: 197-288

HAHN, KA, RICHARDSON, RC, KNAPP, DW 1992: Canine malignant mammary neoplasia: Biologic behavior, diagnosis, and treatement alternatives. J Am Anim Hosp Assoc 28: 251-256

JOHNSON, SD 1993: Reproductive systems. In.: SLATTER, D (Ed): Textbook of small animal surgery, 2nd edition. Saunders, Philadelphia, pp. 2177-2192 
MAC VEAN, DW, MONLUX, AW, ANDERSON, PS, SILBERG, SL, ROSZEL, JF 1978: Frequency of canine and feline tumors in a defined population. Vet Pathol 15: 700-715

MISDORP, W 1988: Canine mammary tumours: Protective effect of late ovariectomy and stimulating effect of progestins. Vet Q 10: 26-33

MITCHELL, L, DE LA IGLESIA, FA, WENKOFF, MS, VAN DREUMEL, AA, LUMB, G 1974: Mammary tumors in dogs: Survey of clinical and pathological characteristics. Canad Vet J 15: 131-138

MOE, L 2001: Population-based incidence of mammary tumours in some dog breeds. J Reprod Fertil Suppl 57: 439-443

MOULTON, JE, TAYLOR, DO, DORN, CR, ANDERSEN, AC 1970: Canine mammary tumors. Pathol Vet 7: 289-320

MOULTON, JE 1990: Tumors of the mammary gland. In: MOULTON, JE (Ed).: Tumors in domestic animals. University of California Press, London, pp. 518-552

MULLIGAN, RM 1975: Mammary cancer in the dog: A study of 120 cases. Am J Vet Res 36: 1391-1396

PRIESTER, WA 1979: Occurrence of mammary neoplasms in bitches in relation to breed, age, tumor type, and geographical region from which reported. J Small Anim Pract 20: 1-11

REJTHAR, A 2002: Biologie vzniku a růstu nádorů. In: REJTHAR, A,VOJTĚŠEK, B (Ed).: Obecná patologioe nádorového růstu, Grada Publishing, Praha, pp.15-104

SANDERSLEBEN, J 1958: Beitrag zur Frage der Malignität der Mammatumoren des Hundes. Mh Tierheilk 11: 191-198

SCHNEIDER, R, DORN, CR, TAYLOR, DO 1969: Factor influencing canine mammary cancer developments and post surgical survival. J Natl Cancer Inst 43: 1249-1261

SCHNEIDER, R 1970: Comparison of age, sex and incidence rates in human and canine breast cancer. Cancer 26: 419-426

SONNENSCHEIN, EG, GLICKMAN, LT, GOLDSCHMIDT, MH, MCKEE, LJ 1991: Body conformation, diet, and risk of breast-cancer in pet dogs - a case-control study. Am J Epidemiol 133: 694-703

TAYLOR, GN, SHABESTARI, L, WILLIAMS, J, MAYS, CW, ANGUS, W, MC FARLAND, S 1976: Mammary neoplasia in a closed beagle colony. Cancer Res 36: 2740-2743 